\title{
Trends and Determinants of Unintended Pregnancy Occurrence Among Married Women Aged 15-49 Years in Indonesia
}

\author{
Mawasumi Ayu Andini ${ }^{1}$, Rini Mutahar ${ }^{2, *}$, Yeni $^{2}$ \\ ${ }^{I}$ Setiabudi Subdistrict Community Health Centre, Jakarta, Indonesia \\ ${ }^{2}$ Universitas Sriwijaya, Jl. Palembang Prabumulih KM.32, 30662, Ogan Ilir, Indonesia \\ *Corresponding author.Email: rini_mutahar@ffkm.unsri.ac.id
}

\begin{abstract}
Complications resulting from unsafe abortion are among the major complications which account for nearly $75 \%$ of all maternal deaths. Unsafe abortion is risky for women with an unintended pregnancy. Unintended pregnancy is one of the important issues in public health because there is a negative relationship with the health and social impacts for both mother and children. This study aims to determine trends and analyses the determinants of unintended pregnancy in married woman aged 15-49 in Indonesia. The secondary data used in this study are Indonesia Demographic and Health Survey (IDHS) 2002/03, 2007, and 2012 to display the trends and IDHS 2012 to analyze factors associated with unintended pregnancy. This study is a quantitative study using cross sectional design with married woman aged 15-49 years who had pregnancy/birth and currently pregnant at the time of survey as the study population. Data analysis was done with complex sample from univariate, bivariate by using chi square analysis, and multivariate by using multiple logistic regression analysis. The results shows the increase and decrease of unintended pregnancy based on IDHS 2002/03, 2007 , and $2012(17,1 \%, 20,3 \%, 14,7 \%)$. The result of the study based on IDHS 2012 shows that the variables significant associated to the incidence of unintended pregnancy included the use of planning methods $(\mathrm{PR}=1,91)$, knowledge of contraception methods $(\mathrm{PR}=0,73)$, age $(\mathrm{PR}=1,97)$, parity $(\mathrm{PR}=3,25)$, birth spacing $(\mathrm{PR}=0,76)$, residents $(\mathrm{PR}=1,29)$, age at first marriage $(\mathrm{PR}=1,33)$, knowledge of ovulation cycle $(\mathrm{PR}=1,31)$, woman participation in household decision making $(\mathrm{PR}=1,52)$. Parity is the most dominantly influencing variable with unintended pregnancy incidence after other variables control $(\mathrm{PR}=2,33)$. Contraception program for fertile couples is important to reduce the unintended pregnancy issue by focusing on the effectivity of KB or birth control method, ideal pregnancy planning, and related mother-infant health program so that the welfare of the family can be maintained and improved, decreasing the fertility rate, unsafe abortion and maternal mortality.
\end{abstract}

Keywords: married women, unintended pregnancy, IDHS

\section{INTRODUCTION}

Target to reduce maternal mortality ratio $(M M R)$ included in SDGs in 2030 is 70 deaths per 100.000 live births [1]. WHO estimates that the global maternal mortality rate reaches 216 maternal deaths per 100.000 live births and around $99 \%$ or 302.000 maternal deaths occurs in developing countries with the maternal mortality ratio reaching 239 per 100.000 live births [2]. In Indonesia, SDKI 2012 shows that maternal mortality ratio reached 359 per 100.000 live births.

Complications resulting from unsafe abortion are among the major complications which acccount for nearly $75 \%$ of all maternal deaths [3]. Unsafe abortion is a risk for women with unintended pregnancies who does not have enough knowledge or limited access to contraception and safe abortion service [4]. Worldwide in 2012, total pregnancy rate reached 213,4 million and 85,4 million or approximately $40 \%$ were unintended pregnancies with the average number of 53 per 1000 women aged 15-44 years [5]. In developing countries, the prevalence of unintended pregnancies is about $49 \%$ or 93,1 million of 190 million pregnancies with an average number of unintended pregnancies reahing 54 per 1000 women aged 5-44 years5. Unintended pregnancies mostly occur in married couple [6]. Based on Basic Health Study (Riskesdas) data in 2010, with the respondents of married women aged 10-59 years stated that unintended pregnancies happened to about $42,9 \%$ of women aged $>35$ years, $44,5 \%$ of women with elementary school level of education and $55,9 \%$ of women settled in urban areas [7]. Women who understands their ovulation cycle reduce the risk of unintended pregnancy 0,55 times than women who did not understand their ovulation cycle [8] (OR 0,55; 95\% CI 0,35-0,85). Unintended pregnancy occurred because couples did not use contraceptive method even though they want to space 
pregnancies (unmeet need) or stop having baby. Unintended pregnancy also occurred because of ineffective contraceptive method/ contraceptive failure and discontinuity of contraception use [9]. The aim of this study was to determine the trends of unintended pregnancy and analyze several factors related to unintended pregnancy in married women aged 15-49 years in Indonesia

\section{METHOD}

This study uses secondary data from Indonesia Demography Health Survey (IDHS) at 2002/03, 2007 and 2012. SDKI data from year 2002/03, 2007 and 2012 used to determine trends of unintended pregnancy and only used SDKI data 2012 to analyze the determinants of unintended pregnancy of married women aged 15-49 years in Indonesia. The samples of this study are married women, had been pregnant/ gave birth and pregnant during the survey. The study is quantitative study and using cross-sectional design. Data analysis performed was univariate, bivariate by chi-square statistic test and multivariate by predictive models of regression logistic statistical test. In this study, the variables studied are $K B$ (contraception) methods, knowledge of $K B$ method, knowledge of ovulation cycle, age, parity, birth spacing, media information, education, economic status, residence, age on first marriage and women's participation in households decision making that affects the occurrence unintended pregnancies.

\section{RESULTS AND DISCUSSION}

The trend below indicate the occurence of unintended pregnancies based on SDKI 2002-2003, SDKI 2007 and SDKI 2012. The data indicates that there is an increase of unintended pregnancies from $17,1 \%$ (SDKI 2002-2003) to $20,3 \%$ (SDKI 2007) then decreased into $14,7 \%$ at SDKI 2012. (figure 1).

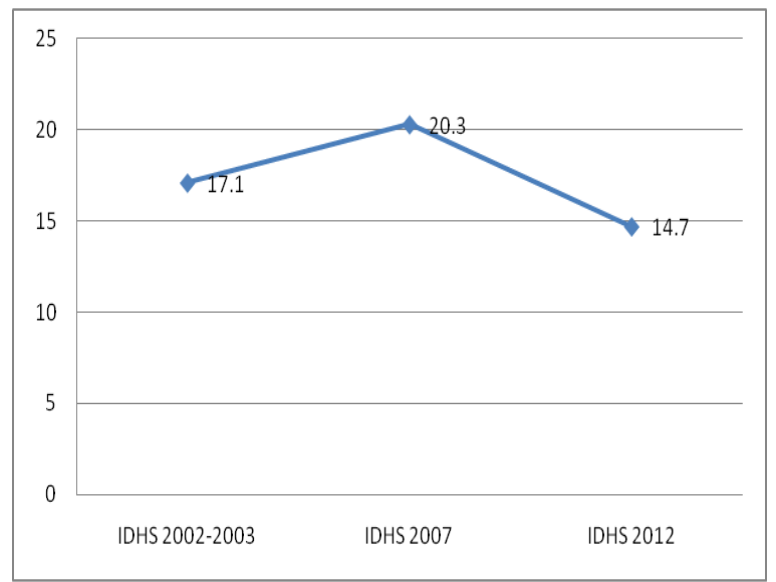

Figure 1. Unintended pregnancy trends on married women aged 15-49 years in Indonesia

The occurrence of unintended pregnancy on married women in Indonesia in 2012 reached 14,6\%. Almost all women who became respondents use $\mathrm{KB}$ method, which is $91,1 \%$ of respondents. The difference between literate and illiterate women about $\mathrm{KB}$ method is about $27 \%$. The data indicates that $19,9 \%$ women knew the ovulation cycle. $75,1 \%$ of respondents are women aged $20-35$ years who were pregnant/gave birth. $85,8 \%$ are women who have a parity of 1-3 children. Almost half of respondents are women who has birth spacing of 59 months or more, which is about $54,2 \%$.

Table 1. Univariate Analysis

\begin{tabular}{lcc}
\hline \multicolumn{1}{c}{ Variable } & $\mathbf{n = 1 4 2 4 6}$ & $\mathbf{\%}$ \\
\hline Unintended pregnancies & & \\
$\quad$ Yes & 2.086 & 14,6 \\
$\quad$ No & 12.160 & 85,4 \\
KB Method Usage & & 91,1 \\
$\quad$ Yes & 12.975 & 0,9 \\
$\quad$ No & 1.217 & 36,5 \\
Knowledge of KB Method & 5.202 & 63,5 \\
$\quad$ Low & 9.044 & 19,9 \\
$\quad$ High & & 80,1 \\
Knowledge of Ovulation Cycle & 2.836 & 3,2 \\
$\quad$ Yes & 11.410 & 75,1 \\
$\quad$ No & & 21,7 \\
Age & 463 & \\
$\quad<20$ Years Old & 10.836 & 14,2 \\
$\quad 20-35$ Years Old & 3.138 & 85,8 \\
$\quad>35$ Years Old & & \\
Parity & 2.030 & 9,4 \\
$\quad \geq 4$ people & 12.216 & 36,3 \\
$1-3$ people & & 54,2 \\
Birth Space* & 839 & \\
$\quad<24$ Months & 3.238 & \\
$24-58$ Months & 4.834 & \\
$\quad \geq 59$ Months & & \\
Education & & \\
\hline
\end{tabular}




\begin{tabular}{lcc} 
No Formal Education & 240 & 1,7 \\
Elementary School & 4.550 & 31,9 \\
Junior High School & 3.548 & 24,9 \\
Senior High School & 4.171 & 29,3 \\
Academy & 665 & 4,7 \\
University & 1.072 & 7,5 \\
Information Media & & \\
Exposed & 12.508 & 87,8 \\
Not exposed & 1.738 & 12,2 \\
Economy Level & & \\
Low & 2.820 & 19,8 \\
Middle-low & 2.756 & 19,3 \\
Middle & 2.847 & 20,0 \\
Middle high & 3.056 & 21,4 \\
High & 2.767 & 19,4 \\
Residence & & \\
Urban & 7.139 & 50,1 \\
Rural & 7.107 & 49,9 \\
First Marriage age & & \\
$\quad \leq 20$ Years Old & 8.004 & 56,2 \\
$\quad>20$ Years Old & 6.242 & 43,8 \\
Women Participation on Taking Households Decision & & \\
Husband & 790 & 5,5 \\
Respondent & 878 & 6,2 \\
Respondent with husband & 12.578 & 88,3 \\
\hline
\end{tabular}

*First child does not have birth spacing

Based on education level, almost one-third respondents were elementary school-educated women, which makes around $31,9 \%$ respondents. Most women were informed by media, which is about $87,8 \%$. According to the economic status, all of them are balanced, placed in all five economic categories. Based on the residence at that survey time, there is no specific differences/ balance between women settled in urban with rural areas. More than half was first got married at the age less than or equal to 20 years old. The majority of the household decision is done by respondents together with their husbands, which is $88,3 \%$ of total respondents. (Table 1.)

Table 2. Bivariate Analysis of Factors Associated with the Occurrence of Unintended Pregnancy

\begin{tabular}{|c|c|c|c|c|c|c|c|}
\hline \multirow{3}{*}{ Variable } & \multicolumn{4}{|c|}{ Unintended Pregnancy } & \multirow{3}{*}{$\mathbf{P R}$} & \multirow{3}{*}{$95 \% \mathrm{CI}$} & \multirow{3}{*}{ pvalue } \\
\hline & \multicolumn{2}{|c|}{ Yes } & \multicolumn{2}{|c|}{ No } & & & \\
\hline & $n=2086$ & $\%$ & $n=12160$ & $\%$ & & & \\
\hline \multicolumn{8}{|c|}{ KB method usage } \\
\hline Yes & 1.984 & 15,3 & 10.990 & 84,7 & 1,910 & $1,485-2,458$ & $<0,0001^{*}$ \\
\hline No & 102 & 8,0 & 1.170 & 92,0 & & & \\
\hline \multicolumn{8}{|c|}{ Knowledge of KB method } \\
\hline Low & 618 & 11,9 & 4.583 & 88,1 & 0,732 & $0,644-0,833$ & $<0,0001^{*}$ \\
\hline High & 1.468 & 16,2 & 7.757 & 83,8 & & & \\
\hline \multicolumn{8}{|c|}{ Knowledge of ovulation cycle } \\
\hline Yes & 512 & 18,1 & 2.324 & 81,9 & 1,310 & $1,133-1,515$ & $<0,0001^{*}$ \\
\hline No & 1.573 & 13,8 & 9.836 & 86,2 & & & \\
\hline \multicolumn{8}{|l|}{ Age } \\
\hline$<20 \&>35$ & 726 & 23,9 & 2.312 & 76,1 & 1,970 & $1,750-2,218$ & $<0,0001^{*}$ \\
\hline $20-35$ & 1.360 & 12,1 & 9.848 & 87,9 & & & \\
\hline \multicolumn{8}{|l|}{ Parity } \\
\hline$\geq 4$ & 732 & 36,1 & 1.298 & 63,9 & 3,255 & $2,912-3,639$ & $<0,0001^{*}$ \\
\hline $1-3$ & 1.354 & 11,1 & 10.862 & 88,9 & & & \\
\hline
\end{tabular}




\begin{tabular}{|c|c|c|c|c|c|c|c|}
\hline \multicolumn{8}{|l|}{ Birth spacing** } \\
\hline$<24 \& \geq 59 \mathrm{mo}$ & 1.099 & 19,4 & 4.574 & 80,6 & 0,759 & $0,677-0,850$ & $<0,0001 *$ \\
\hline $24-58 \mathrm{mo}$ & 827 & 25,5 & 2.411 & 74,5 & & & \\
\hline \multicolumn{8}{|l|}{ Education } \\
\hline Low & 1.257 & 15,1 & 7.081 & 84,9 & 1,074 & $0,947-1,218$ & 0,264 \\
\hline High & 829 & 14,0 & 5.079 & 86,0 & & & \\
\hline \multicolumn{8}{|c|}{ Information media } \\
\hline Exposed & 1.853 & 14,8 & 10.655 & 85,2 & 1,106 & $0,936-1,306$ & 0,233 \\
\hline Unexposed & 233 & 13,4 & 1.505 & 86,6 & & & \\
\hline \multicolumn{8}{|l|}{ Economic level } \\
\hline Low & 827 & 14,8 & 4.856 & 85,2 & 1,070 & $0,90-1,263$ & 0,423 \\
\hline Middle & 447 & 15,7 & 2.422 & 84,3 & 1,149 & $0,948-1,393$ & 0,156 \\
\hline High & 811 & 13,9 & 5.051 & 86,1 & Reff & & \\
\hline \multicolumn{8}{|l|}{ Residence } \\
\hline Urban & 1.176 & 16,5 & 5.963 & 83,5 & 1,288 & $1,122-1,478$ & $<0,0001^{*}$ \\
\hline Rural & 909 & 12,8 & 6.198 & 87,2 & & & \\
\hline \multicolumn{8}{|l|}{ First marriage age } \\
\hline$\leq 20$ & 1.316 & 16,4 & 6.688 & 83,6 & 1,334 & $1,175-1,514$ & $<0,0001^{*}$ \\
\hline$>20$ & 770 & 12,3 & 5.472 & 87,7 & & & \\
\hline \multicolumn{8}{|c|}{ Women participation on taking decision } \\
\hline Husband & 109 & 13,8 & 681 & 86,2 & 0,961 & $0,713-1,297$ & 0,796 \\
\hline Respondent & 177 & 20,1 & 701 & 79,9 & 1,507 & $1,183-1,920$ & $0,001 *$ \\
\hline $\begin{array}{l}\text { Respondent \& } \\
\text { husband }\end{array}$ & 1.800 & 14,3 & 10.778 & 85,7 & Reff & & \\
\hline
\end{tabular}

Used KB method, knowledge of KB methods, knowledge of ovulation cycle, age, parity, birth spacing, residence, first marriage age and women's participation on households decision making were statistically significant and related to unintended pregnancy. Education, information media and economic level were statistically unrelated to unintended pregnancy. (Table 2.)

Table. 3 Multivariate analysis of factors associated with occurrence of unintended pregnancy

\begin{tabular}{lcccc}
\hline \multirow{2}{*}{ Variable } & \multicolumn{2}{c}{ Model I } & Model II \\
\cline { 2 - 5 } & pvalue & Adjusted PR $(95 \%$ CI $)$ & pvalue & Adjusted PR (95\% CI) \\
\hline KB method usage & $<0,0001$ & $1,789(1,292-2,477)$ & 0,001 & $1,781(1,286-2,464)$ \\
Knowledge of KB method & $<0,0001$ & $0,655(0,545-0,786)$ & $<0,0001$ & $0,647(0,541-0,774)$ \\
Knowledge of ovulation cycle & $<0,0001$ & $1,470(1,200-1,802)$ & $<0,0001$ & $1,484(1,213-1,816)$ \\
Age & $<0,0001$ & $1,791(1,478-2,169)$ & $<0,0001$ & $1,785(1,474-2,162)$ \\
Parity & $<0,0001$ & $2,344(1,952-2,815)$ & $<0,0001$ & $2,337(1,946-2,806)$ \\
Birth Spacing & $<0,0001$ & $0,699(0,600-0,814)$ & $<0,0001$ & $0,694(0,596-0,809)$ \\
Education & 0,453 & $0,934(0,781-1,117)$ & - & - \\
Information media & 0,010 & $1,337(1,072-1,667)$ & 0,008 & $1,343(1,078-1,673)$ \\
Economic level (Low) & 0,014 & $1,336(1,060-1,686)$ & 0,018 & $1,315(1,048-1,649)$ \\
Economic level (Middle) & 0,029 & $1,287(1,026-1,614)$ & 0,034 & $1,273(1,019-1,590)$ \\
\hline
\end{tabular}




\begin{tabular}{|c|c|c|c|c|}
\hline \multicolumn{5}{|l|}{ Economic level (High)* } \\
\hline Residence & 0,001 & $1,413(1,142-1,748)$ & 0,001 & $1,421(1,149-1,757)$ \\
\hline First marriage age & 0,011 & $1,255(1,054-1,494)$ & 0,019 & $1,229(1,035-1,460)$ \\
\hline $\begin{array}{l}\text { Women participation on taking } \\
\text { decision (Husband) }\end{array}$ & 0,880 & $1,024(0,737-1,422)$ & 0,881 & $1,025(0,738-1,424)$ \\
\hline $\begin{array}{l}\text { Women participation on taking } \\
\text { decision (Respondents) } \\
\text { Women participation on taking } \\
\text { decision (Respondent } \\
\text { husband)* }\end{array}$ & 0,006 & $1,487(1,121-1,972)$ & 0,006 & $1,485(1,119-1,969)$ \\
\hline
\end{tabular}

Statistically significant factors that influence the occurrence of unintended pregnancy are usage of $\mathrm{KB}$ method, knowledge of KB methods, knowledge of ovulation cycle, age, parity, birth spacing, media information, economic status, residence, first marriage age and women's participation on household decision making. Parity is the most dominant variable that affects the occurrence of unintended pregnancy after controlling these variables; KB method usage, knowledge of KB method, knowledge of ovulation cycle, age, parity, birth spacing, information media, economic level, residence, first marriage age and women participation on taking households decisions. (Table 3.)

The result of this study shows that almost one-eighth of total pregnancies in Indonesia were unintended pregnancies. Trends show an increase between SDKI 2002-03 and SDKI 2007 then there is a decrease in SDKI 2012. Judging from various factors that influence unintended pregnancy on married women, there is statistically significant relation between the use of $\mathrm{KB}$ (contraception) with the occurrence of unintended pregnancy. This study indicates that women who use $\mathrm{KB}$ were more likely to had an unintended pregnancy.

This study result was in-line with the previous study in Ethiopia and Bangladesh that women who use KB were more at risk to have unintended pregnancy rather than women with no $\mathrm{KB}[8,10]$. This is not in line with previous study that women who use $\mathrm{KB}$ have lower risk of having unintended pregnancy than women who did not use KB11. Unintended pregnancy could happen to non-KB user and also to $\mathrm{KB}$ user who had ineffective $\mathrm{KB}$ method or misuse [12].

There is a statistically significant correlation between knowledge of $\mathrm{KB}$ methods with the occurrence of unintended pregnancy. This study states that women who are illiterate about $\mathrm{KB}$ method have lower risk of having unintended pregnancy rather than literate women. It was not in-line with the previous study which stated the literate women have lower risk of having unintended pregnancy than women who are illiterate about KB method [11]. The lack of knowledge in service providers and acceptors of $\mathrm{KB}$ indicates the lack of basic information about all of the $\mathrm{KB}$ methods, this misinformation could cause low usage of $\mathrm{KB}$ and affect the unintended pregnancy [12].

The knowledge of ovulation cycle has a statistically significant correlation with unintended pregnancy. This study shows that women who understands their ovulation cycle are more risked for having unintended pregnancy than women who did not know their ovulation cycle. It was not in-line with the previous study which argued that women who knows their ovulation cycle have lower risk of having unintended pregnancy than women who does not know about ovulation cycle [8].

Women often had limited information and misunderstand their fertile periods. Knowlede on fertile periods/ ovulation and menstrual cycle is important to control the occurrence of unintended pregnancy. However, there is still misinformation about human reproductive health and contraception due to the lack of accurate information in reproductive health [12].

There is also statistically significant correlation between women's age with the occurrence of unintended pregnancy. The study shows that women younger and older than the age range of this study has a bigger risk for having unintended pregnancy than women aging 20-35 years. This is in-line with previous study which stated that the older the women, the higher their chance of having unintended pregnancy $[10,11]$. Pregnancy in younger age $(<20$ years old) or older age ( $>35$ years old) has a high risk on maternal and child health [12].

Parity or number of children that were born had statistically significant relation with the occurrence of unintended pregnancy. The parity in this study was a major predictor of unintended pregnancy. This study indicates that women who has parity more or equal to 4 children has risk of getting unintended pregnancy. Related to the previous studies which shows that the higher number of children, the more possible for them to have unintended pregnancy [ 8 , $11,15]$. In this study, the average respondents has 2 children so if they have more than or equal to 4 children they have more risk of having unintended pregnancy. The women who has parity more than or equal to 4 children in this study happened to be women aged more than 35 years, so that at the end of the reproductive age they were advised to have no more pregnancy. This is related the fact on maternal health during pregnancy to childbirth, where women older than 35 years old have risky pregnancy.

There is a statistically significant relation between birth spacing with the occurrence of unintended pregnancy. This study interprets that women with birth spacing at risk $(<24$ months $\& \geq 59$ months) have less risk of having unintended pregnancy than women with ideal birth spacing (24-58 months). This is not in line with previous study which stated that women with birth spacing less than 24 months 
had bigger risk to have unintended pregnancy than women with more than or equal to 59 months of birth spacing [8]. This study shows that there is no correlation between women's education with the occurrence of unintended pregnancy. This statement is not in-line with the previous study which declared that there is major statistically correlation between education with the occurrence of unintended pregnancy and women with elementary education level are more risk than women with no formal education [14]. Women with high education tend to get more information than women with lower education.

This study shows no correlation between media information with the occurrence of unintended pregnancy. This result is different with the previous study which stated that there is statistic correlation between information with the occurrence of unintended pregnancy where women who access the media have less risk of having unintended pregnancy than women who did not access the media $[10$, $16,17]$. Women who acess the media information would have improved knowledge about $\mathrm{KB}$ method and tend to choose using KB method to prevent pregnancy. In contrast, this study shows that there is a failure or misuse of $\mathrm{KB}$ method because the proportion of women who uses $\mathrm{KB}$ method reported to experience unintended pregnancies.

This study indicates that there was no correlation between economic and social status with the occurrence of unintended pregnancy. This result was not in-line with the previous studies which stated that there was a statistically significant correlation between economic level/status with the occurrence of unintended pregnancy. Women with low economic status are more likely to have unintended pregnancy than women with higher economic status $[13$, 15]. In this study, the proportion of unintended pregnancy is nearly same in all economic status categories. It was related to the pattern of $\mathrm{KB}$ use where women who are using and not using $\mathrm{KB}$ both are risked for having unintended pregnancy [12].

Their residence significantly and statistically related to the occurrence of unintended pregnancy. This study interpreted that women who settles in urban areas are more risked for having unintended pregnancy than women who settles in rural areas. It is not in-line with the previous study which declares that women who settles in rural areas are more likely to have unintended pregnancy than women settling in urban areas 15 . Women settles in urban areas tend to have higher education and able to access media information so that it improves the usage of KB method which has higher risk for having unintended pregnancy.

There is statistically significant correlation between first marriage age with the occurrence of unintended pregnancy. In this study, women who firs married at less or equal to 20 years old are more risked for having unintended pregnancy than women who first married at age more than 20 years old. In-line with the previous study which also stated that further increase in the age at first marriage might lower the occurrence of unintended pregnancy because the couples are ready and able to have children $[10,15]$.

Women's participation in households decision making has statistically significant correlation with the occurrence of unintended pregnancy. In-line with the previous study which stated that there was a statistically significant correlation between women's participation in households decision making with the occurrence of unintended pregnancy $[17,18]$.

\section{CONCLUSION}

Unintended pregnancy trends on married women aged 15-49 years in Indonesia based on IDHS 2002/03, 2007 and 2012 increased from 2002/03 (17,1\%) and $2007(20,3 \%)$ then decreased in $2012(14,7 \%)$. There is a correlation between KB usage, knowledge of KB methods, knowledge of ovulation cycle, age, parity, birth spacing, residence, first marriage age and women's participation in households decision making with the occurrence of unintended pregnancy in married women aged 15-49 years in Indonesia. Parity was the most dominant variable which influences the occurrence of unintended pregnancy after controlling variables; $\mathrm{KB}$ usage, knowledge of $\mathrm{KB}$ method, knowledge of ovulation cycle, age, birth spacing, residence, first marriage age, media information, economic status and women's participation in households decision making. Target improvement of KB program in order to reduce unintended pregnancy which is to delay pregnancy until aged 20 years or more. Stopping pregnancy at the age about more or equal to 35 years by the steady use of contraceptive method. Families to use pregnancy planning by minimizing amount of parity by having less than 4 children and ideal birth spacing of minimal 24-58 months. For healthcare workers to improve communication, information and education related to contraception or $\mathrm{KB}$ program, methods and maternal \& infant health. Contraception or KB Program is important to reduce unintended pregnancy so that the family welfare can be maintained and improved. Decreasing the number of fertility related to population growth and decreasing the abortion need and reducing maternal mortality.

\section{REFERENCES}

[1] Kementrian Kesehatan RI. (2015). Kesehatan Dalam Rangka Sustainable Development Goals (Sdgs). Jakarta: Rakorpop Kementrian Kesehatan RI.

[2] World Health Organization (WHO), UNICEF, UNFPA, World Bank Group Dan United Nations Population Division. (2015a). Trends In Maternal Mortality: 1990 To 2015. Geneva: World Health Organization (WHO)

[3] World Health Organization Media Centre. (2015b). Maternal Mortality. Http:/Www.Who.Int/Mediacentre/Factsheets/Fs348/En/. [5 Maret 2016]

[4] World Health Organization Media Centre. (2015c). Preventing Unsafe Abortions. Http://Www.Who.Int/Mediacentre/Factsheets/Fs388/En/. [5 Maret 2016]

[5] Sedgh, G., S. Singh, et al. (2014). Intended And Unintended Pregnancies Worldwide In 2012 And Recent Trends. Studies in Contraception45(3): 301-314. 
[6] Sedgh, G., A. Bankole, Et al. (2006). Unintended Pregnancy And Associated Factors Among Nigerian Women. International Contraception Perspectives32(4): $175-184$

[7] Pranata \& Sadewo. (2012). Kejadian Keguguran, Kehamilan Tidak Direncanakan Dan Pengguguran di Indonesia. Buletin Penelitian Sistem Kesehatan 15(2): 180-192.

[8] Habte, D., S. Teklu, Et al. (2013). Correlates Of Unintended Pregnancy In Ethiopia: Results From A National Survey. Journal PLoS ONE8(12).

[9] Barden-O'Fallon, Janine L., et al. (2008). Association between contraceptive discontinuation and pregnancy intentions in Guatemala. Rev Panam Salud Publica/Pan Am J Public Health 23(6).

[10] Rahman, Mosfequr. (2012). Women's Autonomy and Unintended Pregnancy Among Currently Pregnant Women in Bangladesh. Maternal Child Health Journal 16:12061214.

[11] Adhikari, R., K. Soonthorndadha, et al. (2009). Correlates Of Unintended Pregnancy Among Currently Pregnant Married Woman In Nepal. BMC International Health And Human Rights9(17).

[12] Brown, S. \& Eisenberg, L. (1995) The Best Intentions: Unintended Pregnancy And The Well-Being Of Children \& Families. Washington DC: National Academy Press.

[13] Kassa, N., Y. Berhane, et al. (2012). Predictors Of Unintended Pregnancy In Kersa, Eastern Ethiopia, 2010. Journal Reproductive Health9[1].
[14] Ikamari, L., C. Izugbara, et al. (2013). Prevalence and determinants of unintended pregnancy among women in Nairobi, Kenya. BMC Pregnancy and Childbirth 13(69).

[15] Bastola, K., S. Neupane, et al. (2015). Unintended Pregnancy among Married Pregnant Women in Nepal. Journal of Women's Health, Issues and Care4(4).

[16] Geda, N. R. \& T. K. Lako (2011). A population-based study on unintended pregnancy among married women in a district in Southern Ethiopia. Journal of Geography and Regional Planning 4(7): 417-427.

[17] Dutta, M., C. Shekhar, Et al. (2015). Level, Trend And Correlates Of Mistimed And Unintended Pregnancies Among Currently Pregnant Ever-Married Women In India. Journal PLoS ONE10(12).

[18] Acharya, P., R. Gautam, et al. (2015). Factors Influencing Mistimed And Unintended Pregnancies Among Nepali Women (2011 Nepal DHS). Journal Of Biosocial Science: 1-18.

[19] Badan Pusat Statistik (BPS), Badan Koordinasi Keluarga Berencana Nasional (BKKBN), Departemen Kesehatan Indonesia,,Dan Macro International Inc. (MI). (2003). Survei Demografi Dan Kesehatan Indonesia 2002-2003. Jakarta.

[20] Badan Pusat Statistik (BPS), BKKBN, Departemen Kesehatan, Measure DHS ICF Internasional. (2013). Survei Demografi Dan Kesehatan Indonesia 2012 (SDKI 2012). Jakarta: BPS.

[21] Badan Pusat Statistik, Badan Kesehatan Keluarga Berencana Nasional, Kementerian Kesehatan, Macro Internasional. (2008). Survei Demografi Dan Kesehatan Indonesia 2007 (SDKI 2007). Jakarta: BPS. 